\title{
Experimental Research on Rice Husk Ash as Replacement to Cement in Construction Industry
}

\author{
Ashok Kumar. N, Velayutham.T
}

\begin{abstract}
For the past few years, various materials were used to supplement cement as an essential component for high performance concrete mix design in the construction industry. Those materials can be natural, industrial wastes, or by-products etc. Most common substitute materials are fly ash, Silica Fume and Rice Husk Ash. The aim of the study is to find the suitability of the rice husk ash as a pozzolanic material for cement replacement in mortar and concrete and to assess the effect of Rice Husk Ash (RHA) on concrete. An attempt has been carried out to establish the strength factor of concrete using RHA as a base material to replace cement and satisfies the structural properties of concrete such as Consistency, compressive strength, flexural strength etc. The replacement levels of the cement by mass: 0, 5, 10, 15, 20 and $25 \%$ for rice husk ash were chosen for a curing periods of 3 days, 7 days, 28days and 56days.
\end{abstract}

Keywords: Rice Husk Ash-. Concret-Compressive strength-Flexural strength.

\section{INTRODUCTION}

The outer part of white rice grain contains high amount of silica concentration and the concentration is about 80-88\%.After removing the outer part, which is named as Rice husk. Then this rice husk is burn up to become a rice husk ash (RHA) and it is contributed about $20 \%$ of its weight [Anwar 2001]. RHA is a pozzolanic material and it was stated by [ Tashima 2004].The pozzolanic materials are classified into two categories. The first one is natural pozzolans, which can be of volcanic origin and the second one is man-made pozzolans, which includes industrial by-products such as Fly Ash (FA), Rice Husk Ash (RHA), Silica Fume (SF), Ground

Granulated Blast Furnace Slag (GGBS) etc. The cost of concrete gets reduced by the replacement of RHA and also the workability improves and has beneficial effect on heat hydration and permeability of concrete. (Sata et al 2007).

In construction industry, Cement is the common flexible material and widely utilized for different purpose. The development of the construction industry at a universal level needs more and more amount of Portland cement for sustainable development. Environmental pollution caused due to manufacture of cement was a major source of pollution to the environment, for example manufacturing of Portland

cement is an energy intensive process and releases very large amount of greenhouse gases into the atmosphere, which affect the earth's ecosystem. [1and 2].

Revised Version Manuscript Received on August 19, 2019.

Ashok Kumar. N, Asst. Professor, Department of Civil Engineering, Faculty of Engineering and Technology, Annamalai university, Annamalai Nagar.608002, Tamil Nadu, India. (email:ashokviji.2002@gmail.com)

Velayutham. T, Asst. Professor, Department of Civil Engineering, Faculty of Engineering and Technology, Annamalai university, Annamalai Nagar.608002, Tamil Nadu, India. (email: velayutham.au@gmail.com)
Cementitious product, C-S-H (Gel) was obtained when the mineral admixtures react with excess calcium hydroxide by hydration process. The reduction of excess $\mathrm{Ca}(\mathrm{OH})^{2}$ due to pozzolanic reaction improves the durability of concrete by making cement paste more dense and impervious one. The use of pozzolanic material based blended cement concrete is growing rapidly in the construction industry, which will result in saving of energy, environmental protection and conservation of resources. RHA has been successfully used as a pozzolana in commercial production in a number of countries including Columbia, Thailand and India[5]. Mehta and Pirtz [4] found that RHA is very useful to decrease the temperature of mass concrete more than ordinary Portland cement (OPC) concrete. Basha et al 2005. [3] reported that RHA-used concrete holds better strength, low shrinkage and higher durability than OPC concrete. The use of pozzolanic material based blended cement concrete is growing rapidly in the construction industry, which will result in saving of energy, environmental protection and conservation of resources. A large quantity of RHA is also generated from the agricultural sector. These by-products develop serious environmental problems if not utilized properly.

\section{EXPERIMENTAL PROCEDURE MATERIALS}

\subsection{Concrete}

In this study, M20 grade concrete with achieved target strength $24 \mathrm{MPa}$ was used. It was designed as per IS method. The design mix procedure was carried out as per IS: 10262-2009.

\subsection{Cement}

In this investigation, 53 Grade OPC (Ultra Tech Brand) conforming to IS: 8112-1989 was used. The cement sample was tested as per the procedure given in IS: 4031-1988 and IS: 4032-1985. The test results satisfy the requirements of respective codes and are listed in Tables 1.1. 
Table 1 Physical Properties of Cement

\begin{tabular}{|c|c|c|c|}
\hline S.No & Properties & $\begin{array}{l}\text { Obtained } \\
\text { Results }\end{array}$ & $\begin{array}{l}\text { Requirement as } \\
\text { per IS: } 12269-1987\end{array}$ \\
\hline 1 & Fineness & $25 \%$ & Not more than $10 \%$ \\
\hline 2 & Soundness & $1.5 \mathrm{~mm}$ & $\begin{array}{l}\text { Not more than } \\
10 \mathrm{~mm}\end{array}$ \\
\hline 3 & $\begin{array}{l}\text { Setting time } \\
\text { A) Initial } \\
\text { B) Final }\end{array}$ & $\begin{array}{l}170 \mathrm{~min} \\
260 \mathrm{~min}\end{array}$ & $\begin{array}{l}\text { Not less than } 30 \mathrm{~min} \\
\text { Not less than } 600 \\
\text { min }\end{array}$ \\
\hline 4 & $\begin{array}{l}\text { Compressive } \\
\text { Strength } \\
\text { A) } 3 \text { days } \\
7 \text { days } \\
28 \text { days }\end{array}$ & $\begin{array}{l}40.50 \\
\mathrm{~N} / \mathrm{mm}^{2} \\
51.00 \mathrm{~N} / \\
\mathrm{mm}^{2} \\
67.50 \mathrm{~N} / \\
\mathrm{mm}^{2}\end{array}$ & $\begin{array}{l}\text { Not less than } 27 \mathrm{~N} / \\
\mathrm{mm}^{2} \\
\text { Not less than } 37 \mathrm{~N} / \\
\mathrm{mm}^{2} \\
\text { Not less than } 53 \mathrm{~N} / \\
\mathrm{mm}^{2}\end{array}$ \\
\hline 5 & $\begin{array}{l}\text { Standard } \\
\text { consistency }\end{array}$ & $28.50 \%$ & - \\
\hline 6 & $\begin{array}{l}\text { Specific } \\
\text { gravity }\end{array}$ & 3.1 & - \\
\hline
\end{tabular}

\subsection{Aggregates}

The coarse aggregate of $10 \mathrm{~mm}$ and $20 \mathrm{~mm}$ size crushed stone angular aggregates conforming to IS 383-1979. The fine aggregate was naturally occurring sand was used conforming to zone II as per IS 383-1979. The properties of fine and coarse aggregates used are presented in Table 2.

Table 2 Properties of Aggregates and Rice Husk Ash

\subsection{Rice Husk Ash}

Rice Husk Ash is the ash that is obtained by burning the rice husk until it gets reduced by $25 \%$. The Rice Husk for this study was obtained at Chidambaram. These Husks then were grinded until fine ash is being produced. Further to remove the impurities, these ashes were sieved by 600 micron. The usage of RHA reduces the waste from the rice mills. It makes surroundings clean and becomes a partial replacement for cement. Some other methods also involved in collection of Rice Husk Ash. Physical properties of RHA are presented in Table 2.

\subsection{Water}

Potable water is generally considered fit for making concrete. Water should be free from acids, oils, alkalies or other organic impurities. Water reacts chemically with the cement to form a cement paste in which inert aggregate are held in suspension until cement paste are hardened. and it will also serve as a lubricant in the mixture of fine aggregates and cement. Clean Potable water as acquired from Department of Civil and Structural Engg., Annamalai University was used for mixing and curing of concrete.

\begin{tabular}{cccc}
$\begin{array}{c}\text { Properti } \\
\text { es }\end{array}$ & $\begin{array}{c}\text { Fine } \\
\text { Aggregate }\end{array}$ & $\begin{array}{c}\text { Coarse } \\
\text { Aggregate }\end{array}$ & $\begin{array}{c}\text { Rice } \\
\text { Hisk Ash }\end{array}$ \\
\hline $\begin{array}{c}\text { Water } \\
\text { Absorption }\end{array}$ & $2.8 \%$ & $1.11 \%$ & 217 \\
\hline $\begin{array}{c}\text { Specific } \\
\text { Gravity }\end{array}$ & 2.64 & 2.79 & 2.67 \\
\hline Density & $\begin{array}{c}1738 \\
\mathrm{~kg} / \mathrm{m}^{3}\end{array}$ & $\begin{array}{c}1570 \\
\mathrm{~kg} / \mathrm{m}^{3}\end{array}$ & $\begin{array}{c}683 \\
\mathrm{~kg} / \mathrm{m}^{3}\end{array}$ \\
\hline
\end{tabular}

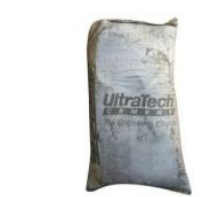

Fig.1

Cement
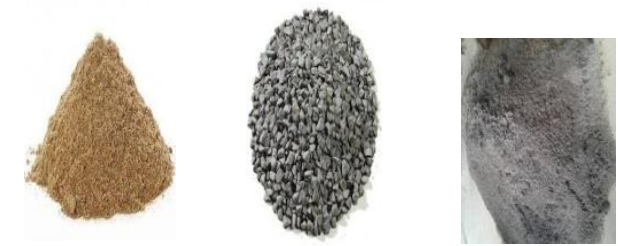
Fig. 2
Fine
Aggregate

Fig.

Coarse

Fig. 4 Rice

Aggregate

\section{RESULTS AND DISCUSSION}

To find the fresh state and hardened properties of cement mortar and concrete at varying percentages of RHA many experiments were conducted.The RHA percentages correspond to $0 \%, 5 \%, 10 \%, 15 \%, 20 \%$ and $25 \%$ by weight of cement was used. Different experiments like consistency test, initial and final setting time were carried out on cement mortar in order to find out the water content necessary to produce as a binder (cement + \% RHA) paste with standard consistency as specified by the IS: 4031 (Part 4) - 1988[15] and IS:4031 (Part 5)-1988 [15]. Table 3 gives the values of normal consistency, initial and final setting time of cement mortar for varying percentages of RHA. Incorporation of $10 \%$ RHA yields optimum in the above tests and presented in Fig. 5.

Table 3 Cement Properties - Consistency \& Setting Time Consistency

\begin{tabular}{|c|c|c|c|c|}
\hline $\begin{array}{r}\% \\
\text { RHA }\end{array}$ & of & $\begin{array}{r}\text { Consist } \\
\text { ency in \% }\end{array}$ & $\begin{array}{l}\text { Initial } \\
\text { setting time } \\
(\mathrm{min})\end{array}$ & \begin{tabular}{l}
\multicolumn{1}{c}{ Final } \\
setting \\
time (min)
\end{tabular} \\
\hline 0 & & 41 & 55 & 622 \\
\hline 5 & & 44 & 46 & 542 \\
\hline 10 & & 46 & 34 & 385 \\
\hline 15 & & 47 & 31 & 410 \\
\hline 20 & & 48 & 30 & 406 \\
\hline 25 & & 50 & 32 & 428 \\
\hline
\end{tabular}

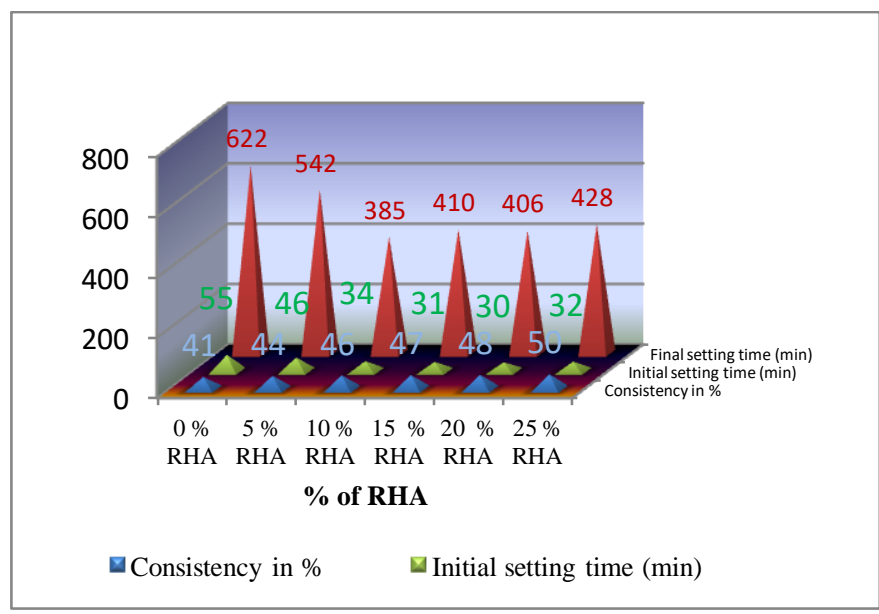

Fig. 5 Properties of Cement Mortar 


\subsection{Compressive Strength}

For curing periods of 3 days, 7 days, 28 days and 56 days the compressive strength were obtained with varying percentages of RHA and it is presented in Fig.. 6. It was found that there was considerable increase in compressive strength from control specimen to specimens with varying percentages of RHA is reported in Table 6. The compressive strength for 3 days and 7 days increases from $11.3 \mathrm{MPa}$ to $24.0 \mathrm{MPa}$ and $13.4 \mathrm{MPa}$ to $26.80 \mathrm{Mpa}$ respectively which can be inferred from inferred from table 6 . The incorporation of $10 \%$ RHA in concrete exhibit an increase of about $15.00 \%$ for 56days compressive strength of RHA concrete. The percentage increases in compressive strength from control specimen to specimens with varying percentages of $10 \%$ RHA were presented.

It can be inferred that the 28 days compressive strength increases from 25.4 MPa to 29.60 MPa with incorporation of $10 \%$ RHA as shown in table6and Fig.6. This $14.19 \%$ enhancement of compressive strength of concrete with $10 \%$ RHA was attributed to the increase in pozzolanic action when RHA was added in concrete. However, for other variations in RHA, there was a reduction in compressive strength of concrete after the incorporation of RHA of about $15 \%$. When the percentage replacement of Rice husk ash was increased, the compressive strength of Rice husk ash concrete was also found to increase gradually up to $10 \%$ replacement and the values gets decreased with the increase in \% of RHA.

Table 6 Compressive Strength Properties

\begin{tabular}{|c|c|c|c|c|}
\hline $\begin{array}{l}\% \text { of } \\
\text { RH } \\
\text { A }\end{array}$ & $\begin{array}{l}3 \quad \text { Days } \\
\text { Compres } \\
\text { sive } \\
\text { Strength }\end{array}$ & $\begin{array}{l}7 \text { Days } \\
\text { Compressi } \\
\text { ve } \\
\text { Strength }\end{array}$ & $\begin{array}{l}\text { 28Days } \\
\text { Compre } \\
\text { ssive } \\
\text { Strengt } \\
\text { h }\end{array}$ & $\begin{array}{l}\text { 56Days } \\
\text { Compre } \\
\text { ssive } \\
\text { Strengt } \\
\text { h }\end{array}$ \\
\hline 0 & 11.30 & 24.00 & 25.4 & 26.40 \\
\hline 5 & 12.00 & 25.30 & 26.30 & 27.35 \\
\hline 10 & 13.40 & 26.80 & 29.60 & 30.30 \\
\hline 15 & 12.90 & 25.85 & 27.25 & 29.95 \\
\hline 20 & 11.42 & 24.92 & 25.90 & 26.90 \\
\hline 25 & 10.54 & 19.00 & 21.20 & 22.30 \\
\hline
\end{tabular}

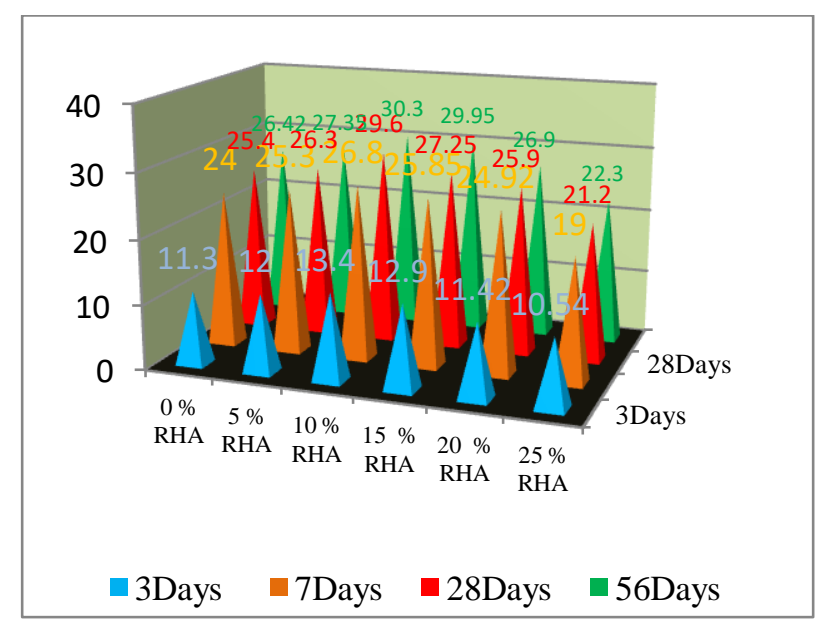

Fig. 6 Compressive Strength Response

\subsection{Flexural Strength}

The improvement of flexural strength from a period of 3 days, 7 days, 28 days and 56 days for mixes with varying percentages of RHA is presented in Fig. 7. The percentage increase in flexural strength from control specimen to specimens with varying percentages of RHA is reported in Table 7. From Fig. 7, it can be inferred that the 3 days and 7days flexural strength increases from 1.27MPa to $1.78 \mathrm{MPa}$ and $1.85 \mathrm{MPa}$ to $1.98 \mathrm{Mpa}$ respectively. The incorporation of $10 \%$ RHA in concrete exhibit an increase of about $38.34 \%$ and $31.16 \%$ for 7 days and 14days compressive strength of RHA concrete. The percentage increase in flexural strength from control specimen to specimens with varying percentages of $10 \%$ RHA appear to have optimum flexural strength as presented in the table7. From Fig.. 7, it can be inferred that the 28 days flexural strength increases from $3.53 \mathrm{MPa}$ to $5.13 \mathrm{MPa}$ with incorporation of $10 \%$ RHA.

When RHA was added in concrete, the flexural strength of concrete has been enhanced by $20 \%$ due to pozzolanic action caused by adding $10 \%$ RHA in concrete. However, for other variations in RHA, there was a reduction in flexural strength of concrete after the incorporation of RHA of about $15 \%$. When the percentage replacement of Rice husk ash was increased, the flexural strength of Rice Husk Ash concrete was also found to increase gradually, up to nearly $10 \%$ replacement and then decreased.

Table 7 Flexural Strength Properties

\begin{tabular}{|c|c|c|c|c|}
\hline 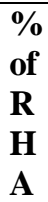 & $\begin{array}{l}\text { 3Days } \\
\text { Flexural } \\
\text { Strengt } \\
\text { h }\end{array}$ & $\begin{array}{l}\text { 7Days } \\
\text { Flexural } \\
\text { Strength }\end{array}$ & $\begin{array}{l}\text { 28Days } \\
\text { Flexural } \\
\text { Strength }\end{array}$ & $\begin{array}{l}\text { 56Days } \\
\text { Flexural } \\
\text { Strength }\end{array}$ \\
\hline 0 & 1.27 & 1.85 & 4.84 & 4.95 \\
\hline 5 & 1.48 & 1.92 & 4.98 & 5.22 \\
\hline 10 & 1.78 & 1.98 & 5.15 & 5.44 \\
\hline 15 & 1.23 & 1.75 & 4.65 & 4.89 \\
\hline 20 & 1.08 & 1.66 & 4.24 & 4.31 \\
\hline 25 & 1.02 & 1.46 & 3.72 & 3.92 \\
\hline
\end{tabular}

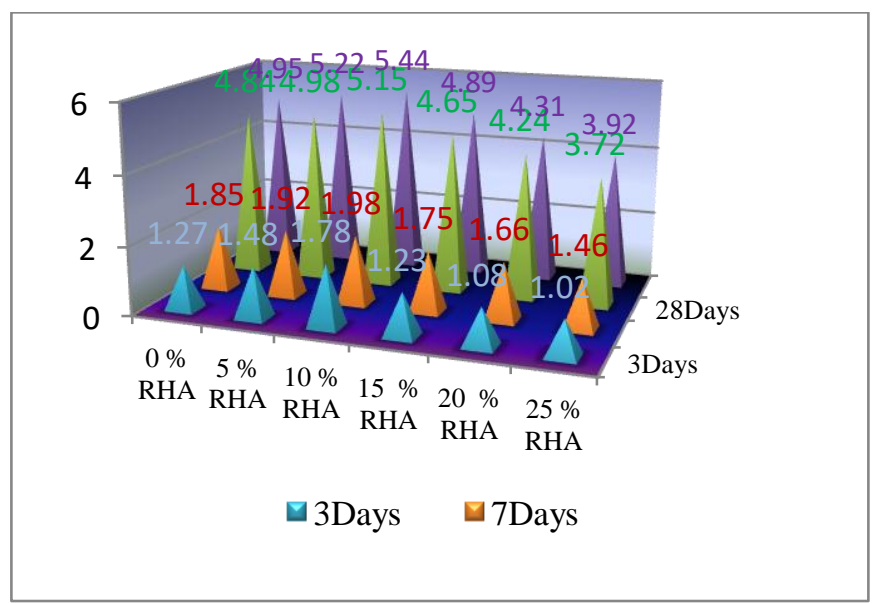

Fig. 7 Flexural Strength Response

\section{CONCLUSION}

The possibility of using Rice husk ash as a partial replacement for cement was investigated in the present work. By finding out the physico-chemical characteristics of RHA, its aptness as a cementitious material was evaluated out to study the influence of RHA on concrete (fresh state and 
hardened state) .To assess the fresh stage properties, Slump values for different $\%$ of RHA of concrete mix at a temperature of $320^{\circ} \mathrm{C}$ was carried out to determine the workability of concrete. Hardened properties like compressive strength and flexural strength properties were evaluated. From the experimental investigation it was found that optimum replacement of Rice Husk ash in cement was to $10 \%$ in terms of workability and strength. Incorporation of $10 \%$ Rice Husk ash in structural concrete exhibit an increase in compressive strength of about $14.19 \%$ which is an optimum ratio that can be used for concrete Similarly. Incorporation of $10 \%$ to $15 \%$ Rice Husk ash in structural concrete gives an increase in flexural strength of about $10 \%$.

\section{REFERENCES}

1. Anwar, M., Miyagawa, T., and Gaweesh, M. 2001. Using rice husk 1. Ahiduzzaman. M. 2007, Rice husk energy technology in ash as a cement replacement material in concrete. In the Proceedings of the 2001 first international Ecological Building Structure Conference. pp. 671- 684.

2. Alex J, Dhanalakshmi J, Ambedkar B (2016) Experimental investigation on rice husk ash as cement replacement on concrete production. Constr BuildMaster, 127:353-362.

3. Basha, E.A., Hashim, R., Mahmud, H.B. and Muntohar, A.S., 2005. Stabilization of residual soil with rice husk ash and cement. Construction and building materials, 19(6), pp.448-453.

4. Khan R, Jabbar A, Ahmad I, Khan W, Naeem A, Mirz J (2012)Reduction in environmental problems using rice-husk ash in concrete. Constr Build Mater 30:360-365.

5. Mehta, P. K. and Pirtz, D. (2000). Use of rice husk ash to reduce temperature in high strezzngth mass concrete. $A C I$ Journal Proceedings, pp. 75: 60-63.

6. Sata, V., Jaturapitakkul, C. and Kiattikomol, K., 2007. Influence of pozzolan from various by-product materials on mechanical properties of high-strength concrete. Construction and Building Materials, 21(7), pp.1589-1598.

7. Tashima, M.M., Silva, C.A.R., Akasaki, J.L., and Barbosa,M.B. 2004. The Possibility of Adding the Rice Husk Ash (RHA) to the Concrete. In the Proceedings of the 2004 International RILEM Conference on the Use of Recycled Materials in Building and Structures. pp. $778-$ 786. 